\section{Jurnal Mitra Pendidikan (JMP Online)}

URL : http://e-jurnalmitrapendidikan.com
JMP Online

Vol. 4, No. 6, 392-403

(C) 2020 Kresna BIP. e-ISSN 2550-0481

p-ISSN 2614-7254

\title{
MENINGKATKAN HASIL BELAJAR MATEMATIKA OPERASI PERKALIAN MELALUI PENDEKATAN MATEMATIKA REALISTIK PADA SSISWA KELAS IV SEKOLAH DASAR INPRES SOPI KECAMATAN MOROTAI JAYA
}

\author{
Nurhani Mahmud \\ Universitas Pasifik Morotai
}

INFORMASI ARTIKEL

Dikirim : 28 Juni 2020

Revisi pertama : 29 Juni 2020

Diterima : 30 Juni 2020

Tersedia online : 02 Juli 2020

Kata Kunci: Pendekatan Matematika

Realistik, Hasil Belajar Matematika

Email: nurhanimahmud877@gmail.com
ABSTRAK

Proses belajar mengajar materi perkalian, bahwa materi tersebut sulit dipahami para siswa, seperti menjumlahkan penjumlahan secara berulang sehingga mengakibatkan pada materi perkalian siswa mampu untuk mengalikan satu bilangan dengan bilangan yang lainnya tetapi jika mengalikan bilangan melebihi satu bilangan, siswa sudah merasa kesulitan untuk mengoperasikannya sehingga dari hasil belajar materi tersebut dari 20 siswa yang mencapai nilai di atas KKM 70 hanya 5 siswa (25\%). Tujuan penelitian tindakan kelas (PTK) ini adalah untuk meningkatkan hasil belajar matematika operasi perkalian melalui pendekatan matematika realistik pada siswa kelas IV SD Inpres Sopi Kecamatan Morotai Jaya. Metode yang digunakan adalah metode penelitian tindakan kelas (PTK). Penelitian dilaksanakan dalam 2 siklus, setiap siklus terdapat 4 tahap yaitu perencanaan, pelaksanaan, observasi dan Refleksi. Untuk meningkatkan hasil belajar matematika siswa digunakan pendekatan matematika realistik sehingga hasil penelitian setiap siklus menunjukkan peningkatan setiap siklus. Pada tindakan siklus 1 tingkat hasil belajar siswa mencapai ketuntasan belajar 35\% dan pada tindakan siklus II, proses kegiatan belajar mengajar telah mengalami peningkatan dengan tuntasan belajar secara klasikal mencapai ketuntasan belajar 90\% dan telah mencapai KKM (70). Penerapam pendekatan matematika realistik dapat meningkatkan hasil belajar siswa tentang operasi perkalian pada siswa kelas IV Sekolah Dasar Inpres Sopi Kecamatan Morotai Jaya. 


\section{PENDAHULUAN \\ Latar Belakang}

Dari hasil observasi guru yang mengajar di kelas IV Sekolah dasar (SD) Inpres Sopi di antaranya, pada saat guru menerangkan materi operasi penjumlahan dan perkalian ada beberapa siswa tidak memperhatikan penjelasan dari guru, siswa tidak bertanya pada saat guru memberikan kesempatan sehingga materi yang diajarkan tidak semua siswa memahaminya. Selain itu dari hasil wawancara peneliti dengan guru tentang proses belajar mengajar materi perkalian, menyatakan bahwa materi tersebut sulit dipahami para siswa, seperti menjumlahkan penjumlahan secara berulang sehingga mengakibatkan pada materi perkalian siswa belum mampu untuk mengalikan satu bilangan dengan bilangan yang lainnya. Tetapi jika mengalikan bilangan melebihi satu bilangan, siswa sudah merasa kesulitan untuk mengoperasikannya sehingga pemahaman siswa tentang perkalian sangat terbatas dan menyebabkan siswa belum mampu mengalikan antar bilangan yang besar sehingga dari hasil belajar materi tersebut dari 20 siswa yang mencapai nilai di atas KKM 70 hanya 5 siswa (25\%).

Untuk memperbaiki mutu pembelajaran diperlukan perubahan dalam pendekatan pembelajaran yang mengaitkan teori dengan kenyataan yang ada di lingkungan sekitarnya. Jika sebelumnya semua pengetahuan berasal dari guru dan ditransfer kepada siswa maka pada saat sekarang guru harus memberikan kesempatan kepada siswa untuk seaktif mungkin berdiskusi dan berkolaborasi, beragumentasi dengan teman sekelas sehingga mereka dapat menemukan sendiri dan pada akhirnya menggunakan matematika untuk menyelesaikan masalah baik individu maupun kelompok. Salah satu alternatif yang sudah dilakukan dan dapat diupayakan dalam meningkatkan mutu pembelajaran adalah dengan menggunakan pendekatan Matematika Realistik (PMR).

PMR merupakan pembelajaran yang dikembangkan untuk mendekatkan matematika kepada siswa. Masalah-masalah nyata dari kehidupan sehari-hari digunakan sebagai titik awal pembelajaran matematika untuk menunjukkan bahwa matematika sebenarnya dekat dengan kehidupan sehari-hari siswa. Pendekatan matematika realistik ini sesuai dengan perubahan paradigma pembelajaran, yaitu dari paradigma mengajar ke paradigma belajar atau perubahan paradigma pembelajaran yang berpusat pada guru ke paradigma pembelajaran yang berpusat pada siswa. Hal ini adalah salah satu upaya dalam rangka memperbaiki mutu pendidikan matematika (Ali 2013:42).

Dari permasalahan di atas peneliti tertarik melakukan Penelitian dengan judul Meningkatkan Hasil Belajar Matematika Operasi Perkalian Melalui Pendekatan Matematika Realistik Pada Ssiswa Kelas IV Sekolah Dasar Inpres Sopi Kecamatan Morotai Jaya.

\section{Rumusan Masalah}

Berdasarkan uraian latar belakang dan batasan masalah di atas dapat di rumuskan masalah penelitian ini adalah Bagaimana meningkatkan hasil belajar matematika operasi perkalian melalui pendekatan matematika realistik pada siswa kelas IV SD Inpres Sopi Kecamatan Morotai Jaya? 


\section{Tujuan Penelitian}

Berdasarkan permasalahan yang akan diteliti tersebut di atas, maka tujuan penelitian tindakan kelas (PTK) ini adalah untuk mengetahui hasil belajar matematika operasi perkalian melalui pendekatan matematika realistik pada siswa kelas IV SD Inpres Sopi Kecamatan Morotai Jaya.

\section{KAJIAN PUSTAKA \\ Pengertian Hasil Belajar}

Belajar adalah Key term, "istilah kunci" yang paling vital dalam setiap usaha pendidikan. Sehingga tanpa belajar sesungguhnya tak pernah ada pendidikan. Belajar merupakan suatu aktivitas atau suatu proses untuk memperoleh pengetahuan, meningkatkan ketrampilan, memperbaiki perilaku dan memperkokoh kepribadian. Menurut para ahli Ngalim (2009:30) belajar adalah suatu proses usaha yang di lakukan seseorang untuk memperoleh suatu perubahan tingkah laku yang baru secara keseluruhan sebagai hasil pengalamannya sendiri dalam interaksi dengan lingkungannya.

\section{Pendekatan Pembelajaran Matematika Realistik}

Pendidikan matematika realistik (PMR) adalah sebuah pendekatan belajar matematika yang dikembangkan oleh sekelompok ahli matematika dari negeri Belanda. PMR dikembangkan pertama kali oleh Freudenthal pada tahun 1971 di Utrecht University Belanda. Menurut Freudenthal (Ariyadi, 2011:15) bahwa belajar matematika adalah suatu aktivitas, sehingga kelas matematika bukan tempat memindahkan matematika dari guru kepada siswa, melainkan tempat siswa menemukan kembali ide dan konsep matematika melalui eksplorasi masalahmasalah nyata.

Langkah - langkah model pembelajaran matematika realistik di dalam proses pembelajaran matematika Waraskamdi (dalam Ariyadi 2011:29) adalah:

1. Memotivasi siswa (memfokuskan perhatian siswa)

2. Mengkomunikasikan tujuan pembelajaran

3. Memulai pelajaran dengan mengajukan masalah (soal)

Mengajukan soal yang "riil" bagi siswa sesuai dengan pengalaman dan tingkat pengetahuannya, sehingga siswa segera terlibat dalam pelajaran secara bermakna

4. Permasalahan yang diberikan sesuai

Permasalahan tentu harus diarahkan sesuai dengan tujuan yang ingin dicapai dalam pelajaran tersebut

5. Siswa mengembangkan atau menciptakan model-model simbolik secara informal terhadap persoalan/masalah yang diajukan

\section{Materi Pembelajaran}

Perkalian adalah operasi matematika penskalaan satu bilangan dengan bilangan lain. Sederhanya perkalian merupakan penjumlahan berulang. Perkalian terdefinisi untuk seluruh bilangan di dalam suku-suku perjumlahan yang diulangulang; misalnya, 3 dikali 4 (seringkali dibaca "3 kali 4") dapat dihitung dengan menjumlahkan 3 salinan dari 4 bersama-sama Fathani (2008:19). 


\section{Sifat Operasi Hitung}

1. Sifat Pertukaran (Komulatif)

\begin{tabular}{|l|l|l|}
\hline Penjumlahan & $\mathrm{a}+\mathrm{b}=\mathrm{b}+\mathrm{a}$ & $2+8=8+2=10$ \\
\hline Perkalian & $\mathrm{a} \times \mathrm{b}=\mathrm{b} \times \mathrm{a}$ & $9 \times 5=5 \times 9=45$ \\
\hline
\end{tabular}

2. Operasi Perkalian

a. Perkalian sebagai penjumlahan berulang Contoh: $5 \times 23=23+23+23+$ $23+23=115$

b. Perkalian langsung (sifat komutatif perkalian) Contoh: $5 \times 23=23 \times 5=$ 115
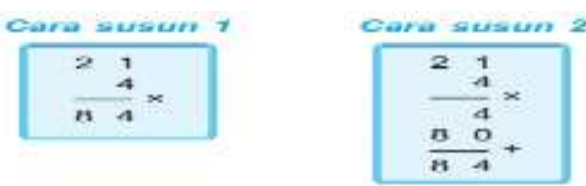

c. Perkalian bersusun:

Perhatikan jumlah lingkaran tiap kotak
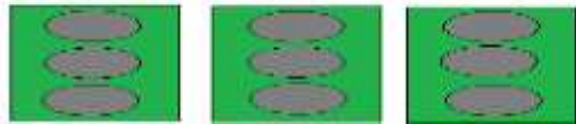

Dari gambar, terlihat bahwa banyak lingkaran seluruhnya.

1 Kotak $=1 \times 3=3$

2 Kotak $=2 \times 3=6$

3 Kotak $=3 \times 3=9$

\section{METODE PENELITIAN}

\section{Jenis Penelitian}

Jenis penelitian yang digunakan adalah Penelitian Tindakan Kelas (PTK) yang dalam bahasa Inggris PTK disebut Classroom Active Research (CAR). Menurut Arikunto (2011:14) PTK adalah suatu kajian yang bersifat reflektif oleh pelaku tindakan yang dilakukan untuk meningkatkan kemampuan rasional dari tindakan tindakan yang dilakukan itu, serta untuk memperbaiki kondisi-kondisi dimana praktek-praktek pembelajaran tersebut dilakukan.

\section{Prosedur Penelitian}

Secara garis besar terdapat tahapan yang lazim dilalui dalam PTK, yakni mencakup kegiatan-kegiatan perencanaan (Planning) tindakan (action), pengamatan (Observing) dan refleksi (Reflecting): 


\section{Gambar 1. Alur PTK Model Kurt Lewin}

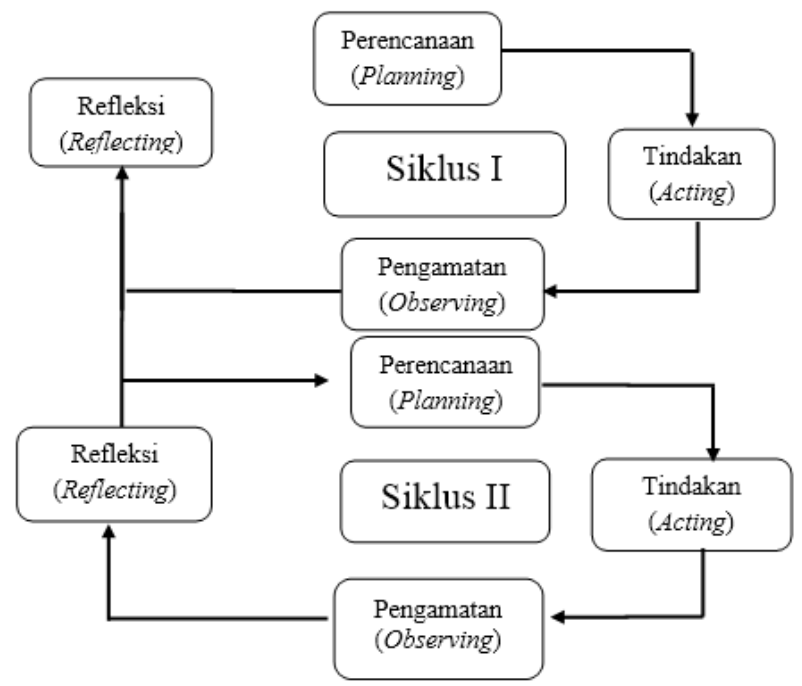

Sumber : Kusuma (2012)

Berdasarkan gambar sebelumnya maka dapat dijelaskan sebagai berikut:

\section{Tahap Perencanaan}

Adapun kegiatan yang dilakukan pada tahap perencanaan ini adalah penyusunan perangkat pembelajaran yang meliputi:

a. Silabus yang dikembangkan oleh tim guru sesuai dengan kurikulum yang berlaku.

b. Rencana pelaksanaan pembelajaran (RPP) yang dikembangkan berdasarkan model pembelajaran PMR

c. Bahan ajar

d. Lembar kerja siswa (LKS) yang berisi tugas-tugas yang harus diselesaikan oleh siswa

e. Menyiapkan lembar tes untuk melihat tingkat keberhasilan siswa.

2. Tahap Pelaksanaan

Kegiatan yang dilaksanakan pada tahap ini adalah implementasi rencana tindakan yang telah dibuat pada tahap perencanaan dengan menggunakan pendekatan matematika realistik kelas IV SD Inpres Sopi untuk meningkatkan hasil belajar siswa. Adapun langah-langkah yang dilakukan pada tahap ini adalah:

a. Kegiatan awal (10 menit) dengan rincian sebagai berikut: guru melakukan apersepsi dengan memberikan pertanyaan untuk mengetahui pengetahuan awal siswa kemudian dilanjutkan dengan menjelaskan kompetensi dasar dan tujuan pembelajaran yang akan dicapai.

b. Kegiatan inti (50 menit) dengan rincian sebagai berikut:

a) Guru mengelompokan siswa ke dalam 4 anggota tim

b) Setiap Peserta didik dalam tim diberi bagian materi yang yang sama

c) Setiap orang dalam tim diberi bagian materi yang ditugaskan

d) Setelah selesai, diskusi sebagai tim ahli setiap anggota kembali ke kelompok asal dan bergantian

e) Mengajar teman satu tim mereka tentang sub bab yang mereka kuasai dan setiap anggota lainnya mendengarkannya 
f) Tim mempresentasikan hasil diskusi

g) Guru memberi evaluasi

c. Penutup

a) Penutup (10 menit) dengan rincian sebagai berikut:

b) Guru memberikan evaluasi kepada siswa tentang model pembelajaran yang telah diterapkan.

3. Tahap Pengamatan

Observasi dilakukan untuk mengetahui pelaksanaan tindakan yaitu apakah pelaksanaan pembelajaran sesuai dengan rencana yang telah disusun sebelumnya. Observasi pelaksanaan pembelajaran dengan pendekatan matematika realistic dilakukan dengan mengisi daftar cek observasi pada saat pelaksanaan pembelajaran dengan pendekatan tersebut. Penilaian dilakukan setelah akhir siklus dengan memberikan tes essay yang dikerjakan secara individu untuk mengukur hasil belajar kognitif siswa.

4. Tahap Refleksi

Pada tahap ini, peneliti bersama guru mengkaji kekurangan dari tindakan yang diberikan. Hal ini dilakukan dengan melihat hasil evaluasi tindakan pada siklus pertama. Jika refleksi ini menunjukan tindakan siklus pertama belum mencapai indikator kinerja maka, dilakukan revisi terhadap rencana pelaksanaan pembelajaran (RPP). Hasil refleksi siklus pertama selanjutnya digunakan sebagai dasar untuk melaksanakan tindakan siklus kedua, begitu seterusnya sampai masalah dapat teratasi

\section{Tempat, Waktu dan Subjek Penelitian}

Penelitian ini dilaksanakan di SD Inpres Sopi Kecamatan Morotai Jaya Kabupaten Pulau Morotai pada mata pelajaran matematika. Penelitian ini dilaksanakan mulai pada bulan September-Oktober tahun pelajaran 2019/2020. Subjek dalam penelitian ini adalah siswa kelas IV SD Inpres Sopi tahun pelajaran 2019/2020 dengan jumlah siswa 20 diantaranya laki-laki 9 dan 11 perempuan.

\section{Teknik Pengumpulan Data}

Sesuai dengan bentuk penelitian di atas, maka dalam penelitian ini digunakan teknik pengumpulan data yang meliputi :

1. Observasi atau pengamatan

Teknik observasi sering diartikan sebagai suatu kegiatan aktivitas yang sempit, yakni memperhatikan suatu masalah dengan menggunakan mata.Di dalam pengertian psikologi observasi meliputi kegiatan pemusatan perhatian terhadap suatu objek dengan menggunakan seluruh alat indera (Arikunto, 2011: 133). Observasi dilaksanakan selama pelaksanaan pembelajaran. Observasi dilakukan oleh observer (guru).

2. Tes

Tes menggunakan isian singkat yang bertujuan untuk mengukur hasil belajar kognitif berdasarkan Kompetensi yang diajarkan. Tes dilakukan pada akhir pembelajaran (post tes). Soal tes dikerjakan oleh setiap siswa dalam waktu 20 menit. 


\section{Teknik Analisis Data}

Untuk menganalisis hasil tes yaitu dilakukan dengan rumus sederhana berikut. Data hasil belajar siswa dianalisis berdasarkan evaluasi untuk mengetahui ketuntasan belajar individu maupun klasikal, dengan cara menganalisis data hasil tes formatif menggunakan kriteria ketuntasan belajar. Ketuntasan belajar jika siswa mampu mencapai nilai $\geq 70$ dan ketuntasan klasikal tercapai $\geq 80$

Dengan menggunakan rumus sebagai berikut:

1. Ketuntasan individual

$$
\text { Ketuntasan individual }=\frac{\text { skor yang di peroleh }}{\text { skor maksimum }} \times 100
$$

2. Ketuntasan Klasikal menurut Aqib dkk (2010:41)

$$
\mathrm{TBK}=\frac{N}{S N} \times 100 \%
$$

Keterangan :

$$
\begin{array}{ll}
\text { TBK } & =\text { Tuntas Belajar Klasikal } \\
\mathrm{N} & =\text { Banyak siswa yang memperoleh nilai } \\
\mathrm{SN} & =\text { Jumlah Siswa }
\end{array}
$$

\section{HASIL PENELITIAN DAN PEMBAHASAN \\ Hasil Penelitian}

Berikut ini dipaparkan hasil penelitian yang terdiri dari hasil belajar matematika dan lembar aktifitas guru dan siswa dalam pembelajaran perkalian dengan menggunakan model pembelajaran matematika realistik.

Pelaksanaan siklus penelitian merupakan kegiatan inti penelitian tidakan kelas. Pada penelitian ini dilakukan dalam dua siklus. Siklus pertama dilaksanakan pada hari senin tanggal 09 September 2019 dan siklus kedua dilaksanakan pada hari 7 Oktober 2019 dan dapat diuraikan setiap siklus sebagai berikut:

\section{Siklus I}

Pelaksanaan Siklus I terbagi menjadi empat tahap, yaitu perencanaan, pelaksanaan, observasi, dan refleksi yang membentuk suatu siklus. Secara lebih rinci, masing-masing tahap dapat dijelaskan sebagai berikut:

a. Perencanaan

Sebelum melaksanakan tindakan, peneliti menyusun rencana -rencana tindakan yang akan dilakukan dalam penelitian meliputi:

1) Menyusun rencana pelaksanaan pembelajaran (RPP). Peneliti menggunakan RPP yang sudah ada, namun dimodifikasi sesuai dengan kebutuhan yaitu memasukkan pendekatan pembelajaran matematika realistik

2) Menyiapkan Bahan Ajar.

3) Menyiapkan Lembar kerja siswa (LKS) yang berisi tugas-tugas yang harus diselesaikan oleh siswa

4) Menyiapkan instrumen tes yang akan dibagikan kepada siswa pada akhir tindakan untuk mengetahui hasil belajar siswa.

b. Pelaksanaan

Tindakan siklus I dilaksanakan selama 3x35 menit. Sebelum mulai proses belajar mengajar peneliti memberikan instrumen observasi kepada 
observer. Peneliti memberikan gambaran tentang pendekatan pembelajaran matematika realistik. Selanjutnya peneliti melakukan proses belajar mengajar sesuai dengan RPP dan pendekatan pembelajaran matematika realistik yang telah disusun oleh peneliti.

a) Kegiatan awal (15 menit)

Sebelum proses pembelajaran berlangsung guru membagi kelompok, setiap pembagian kelompok, siswa diranking sesuai dengan kemampuannya dalam mata pelajaran matematika yaitu dengan cara mengambil kelompok teratas $25 \%$ (5 siswa) dari seluruh siswa yang diambil mulai dari ranking satu, kelompok menengah 50\% (10 siswa) dari seluruh siswa yang diambil dari urutan setelah diambil kelompok teratas dan kelompok bawah $25 \%$ (5 siswa) dari seluruh siswa terdiri dari siswa setelah diambil dari kelompok menengah. Dengan mengorganisasikan siswa ke kelompok-kelompok belajar yang terdiri dari 4 kelompok dengan tiap kelompok terdiri dari 5 siswa yang diambil secara acak dari kelompok teratas, kelompok menengah dan kelompok bawah. Dalam pembagian kelompok tersebut dibagi secara heterogen menurut jenis kelamin, dan prestasi akademik.

b) Kegiatan Inti (70 menit)

Pada pembelajaran ini guru menjelaskan materi pelajaran perkalian, dalam penjelasan materi tersebut guru menanyakan kepada siswa beberapa contoh konkrit perkalian dalam kehidupan sehari-hari, ada beberapa siswa antusias menyebutkan bahwa contoh perkalian diantaranya, penjumlahan yang berulang-ulang, misalnya $2 \times 3=6$ itu sama artinya dengan $2+2+2=6$, namun masih ada peserta didik sebanyak $80 \%$ yang belum memahami perkalian dikarenakan masih kesulitan dalam penjumlahan, selain itu guru memperlihatkan benda-benda/buah-buahan konkrit yang yang digunakan dalam perkalian yang terdapat pada gambar-gambar konkrit. Pada saat guru menyuruh peserta didik menuliskan hasil perkalian yang terdapat pada gambar, hanya ada 5 siswa antusias untuk menjawabnya.

Guru menjelaskan jika dua perkalian dikalikan dengan cara menjumlahkan perkalian secara berulang, tetapi dengan cara tersebut peserta didik belum mengerti dan tidak mampu mengoperasikannya. Hal ini disebabkan karena siswa belum menguasai perkalian dan penjumlahan dengan menjumlahkan bilangan yang berulang-ulang. Untuk mengatasi kesulitan siswa tersebut, guru menggunakan alat peraga yang sangat sederhana seperti menggunakan batu-batu yang mudah didapatkan di lingkungan sekitarnya.

c) Kegiatan akhir (20 menit)

Kegiatan selanjutnya guru memberikan tes kepada seluruh siswa secara individu untuk mengetahui tingkat pemahaman siswa dalam menguasai materi operasi perkalian, kegiatan ini bertujuan untuk mendiagnosis apakah siswa sudah benar-benar memahami tujuan pembelajaran yang telah ditetapkan atau belum. Guru membagikan lembar tes kepada seluruh siswa dan mempersilahkan mengerjakannya secara individu dan tidak diperkenankan bekerjasama dengan teman kelompok 
ataupun teman kelas lainnya. Hal ini dilakukan untuk mengetahui tingkat kemampuan siswa secara individu. Dari hasil tes hasil belajar siswa dapat dilihat pada tabel berikut.

Tabel 1. Rekapitulasi Hasil Belajar Perkalian

\begin{tabular}{|c|c|c|c|}
\hline No & Hasil belajar siswa & Jumlah & Persentase (\%) \\
\hline 1 & Tuntas & 7 siswa & $35 \%$ \\
\hline 2 & Belum tuntas & 13 siswa & $65 \%$ \\
\hline & Jumlah & 20 siswa & $100 \%$ \\
\hline
\end{tabular}

Sumber : Hasil Penelitian, diolah (2019)

c. Observasi

Hasil pengamatan observer pada guru dan siswa antara dalam proses pembelajaran:

1) Ada beberapa siswa yang masih bermain dalam kelas dan ribut saat penjelasan materi dari guru

2) Sebagian siswa masih ada yang terlihat diam ketika guru memberika penjelasan tentang perkalian

3) Suasana kelas ramai saat guru menerapkan pendekatan realistik, siswa belum terbiasa dengan pendekatan pembelajaran ini.

4) Dalam mengerjakan soal evaluasi masih ada siswa yang menyontek dan saling kerjasama dalam menyelesaikan soal latihan

Dari hasil observasi tersebut dapat di simpulkan bahwa dalam proses pembelajaran belum terlaksana dengan baik.

d. Refleksi

Tahap refleksi dilakukan pada akhir siklus yang bertujuan untuk untuk mengetahui sejauh mana hasil yang diperoleh selama tindakan berlangsung. Refleksi merupakan pengkajian terhadap keberhasilan atau kegagalan yang telah dicapai guru dan siswa dalam kegiatan pembelajaran.

\section{Siklus II}

a. Perencanaan

Berdasarkan hasil analisis hasil belajar dan refleksi pada siklus I, maka guru dan observer membuat perencanaan ulang untuk mengembangkan pembelajaran. Pada tahap ini, guru menyusun kembali rencana pelaksanaan pembelajaran (RPP) ulang mengacu pada hasil pembelajaran pada siklus I dengan menggunakan pendekatan pembelajaran realistik dalam meningkatkan hasil belajar matematika siswa tentang perkalian. Adapun perencanaan yang akan di perbaiki pada siklus II yaitu

1. Guru lebih mengaktifkan siswa dalam proses pembelajaran dengan menggunakan pendekaran pembelajaran realistik.

2. Siswa masih kesulitan mengalikan perkalian

3. Guru harus lebih banyak melibatkan siswa dengan benda-benda konkrit

4. Guru lebih memberi motivasi dan membimbing siswa dalam proses pembelajaran

5. Tetap menjaga suasana belajar dikelas agar tetap kondusif dan menyenangkan.

Pada siklus II, tindakan yang direncanakan adalah sebagai berikut: 
1. Menyusun rencana pelaksanaan pembelajaran (RPP) dengan menggunakan alat peraga kertas karton.

2. Menyusun kisi-kisi soal

3. Menyusun lembar observasi aktivitas guru dan siswa

4. Menyusun instrumen

b. Pelaksanaan

Pelaksanaan pembelajaran tentang perkalian dengan menggunakan pendekatan pembelajaran realistik pada siswa kelas IV Sekolah Inpres Sopi untuk siklus II dilaksanakan tiga jam pelajaran dengan alokasi waktu 3 x 35 menit. Pelaksanaan dilakukan pada hari senin, 07 Oktober 2019 pukul 07.30 09.10 WIT yang dihadiri 20 siswa. Proses pembelajaran perkalian dilakukan dengan tiga kegiatan yaitu kegiatan awal, kegiatan inti dan kegiatan akhir.

1. Kegiatan awal (15 menit)

Pada kegiatan awal guru harus mengelola kelas lebih baik lagi agar dalam proses pembelajaran dapat berjalan dengan baik dan tertib. Setelah itu guru menunjuk salah satu dari perwakilaan siswa untuk membaca doa sebelum belajar dan siswa yang lain mengikuti doa bersama, dilanjutkan dengan mengecek kehadiran siswa yang dilakukan oleh guru, dimana pada hari itu semua siswa kelas IV hadir sebanyak 20 siswa.

Pada kegiatan awal guru melakukan apersepsi dengan melakukan tanya jawab tentang materi dikelas sebelumnya dan pada siklus I

2. Kegiatan Inti (70 menit)

Pada pembelajaran ini guru menjelaskan materi pelajaran perkalian, dalam penjelasan materi tersebut guru menanyakan kepada siswa beberapa contoh konkrit perkalian dalam kehidupan sehari-hari, ada beberapa siswa antusias menyebutkan bahwa contoh perkalian diantaranya, penjumlahan yang berulang-ulang, misalnya $2 \times 2=4$ itu sama artinya dengan $2+2=4$, dari penjelasan guru tersebut, siswa sebanyak $80 \%$ yang sudah memahami perkalian dikarenakan sudah tidak lagi kesulitan dalam penjumlahan, selain itu guru memperlihatkan benda-benda/buah-buahan konkrit yang yang digunakan dalam perkalian yang terdapat pada gambar-gambar konkrit. Pada saat guru menyuruh siswa menuliskan hasil perkalian yang terdapat pada gambar, sudah $80 \%$ siswa antusias untuk menjawabnya.

3. Kegiatan akhir

Untuk mengerjakan tes telah selesai. Sebelum dikumpulkan, guru mengingatkan kepada seluruh siswa untuk mengecek kembali jawaban yang telah dikerjakan, kemudian siswa diminta mengumpulan lembar jawabannya. Dari hasil tes tersebut dapat dilihat pada tabel berikut.

Tabel 2. Rekapitulasi Hasil Belajar Perkalian

\begin{tabular}{|c|c|c|c|}
\hline No & Hasil belajar siswa & Jumlah & Persentase (\%) \\
\hline 1 & Tuntas & 18 siswa & $90 \%$ \\
\hline 2 & Belum tuntas & 2 siswa & $10 \%$ \\
\hline \multicolumn{2}{|c|}{ Jumlah } & 20 siswa & $100 \%$ \\
\hline
\end{tabular}

Sumber : Hasil Penelitian, diolah (2019) 
c. Observasi

1) Hasil observasi aktivitas guru

a) Dalam proses pembelajaran guru sudah tampak dominan dalam proses pembelajaran sehingga tidak terjadi kevakuman dalam proses pembelajaran

b) Interaksi guru dan siswa sudah tertib dan penataan waktu yang dirancang oleh peneliti sudah tepat sehingga tiap-tiap langkah pembelajaran sudah tidak terjadi kevakuman sehingga menimbulkan suasana belajar yang sudah kondusif.

c) Guru mendemonstrasikan media dan mengaplikasikan dalam kehidupan sehari-hari pada setiap kelompok dalam menyelesaikan soal

d) Guru sudah tampak dominan memberikan motivasi kepada setiap kelompok untuk bekerjasama dalam menyelesaikan soal tes sehingga memperoleh nilai yang tertinggi dan akan diberikan hadiah

2) Hasil observasi aktivitas siswa

a) Siswa sudah mendengarkan penyampaian tujuan pembelajaran yang di sampaikan guru

b) Sebagian besar siswa telah duduk sesuai dengan kelompoknya yang telah dibagikan guru

c) Sebagian besar siswa menyimak dan memperhatikan penjelasan guru pada saat penyajian materi dan memperagakan alat peraga yang sedang berlangsung.

d) Setiap kelompok bertanya pada guru saat kelompok tersebut jika telah memahami isi dari soal

e) Sudah terdapat siswa yang melakukan aktivitas lain saat menyelesaikan soal tes

\section{d. Refleksi}

Tahap refleksi dilakukan pada akhir siklus yang bertujuan untuk untuk mengetahui seberapa besar hasil yang diperoleh selama tindakan berlangsung. Refleksi merupakan pengkajian terhadap keberhasilan atau kegagalan yang telah dicapai guru dan siswa dalam kegiatan pembelajaran.

Pada proses pembelajaran dengan menggunakan pendekatan pembelajaran realistik, nampak bahwa guru telah melibatkan siswa dengan benda-benda konkrit belum maksimal sehingga siswa sudah tidak mengalami kesulitan mengoperasikan perkalian jadi tidak perlu dilanjutkan dan ditingkatkan pada siklus berikutnya dengan menggunakan pendekatan pembelajaran realistik yang telah didesain oleh peneliti.

Secara umum dapat disimpulkan bahwa dalam pembelajaran perkalian dengan menggunan pendekatan pembelajaran realistik terlaksana dengan baik.

\section{Pembahasan}

Pada hasil belajar siswa dalam penguasaan materi pada siklus I masih dikategorikan belum tuntas, hal ini dapat dilihat dari presentasi yang diperoleh adalah pada siklus pertama ini dari 20 siswa hanya terdapat 7 (35\%). Hasil belajar ini belum mencapai KKM klasikal yaitu 70. Rendahnya hasil belajar siswa pada siklus pertama dikarenakan kurangnya aktivitas siswa dan perhatian dalam proses 
belajar mengajar. Sedangkan hasil belajar pada siklus kedua sudah dikategorikan tuntas karena hasil evaluasi siswa dari 20 siswa terdapat 18 (90\%) yang dinyatakan tuntas hasil belajarnya dan 2 siswa belum tuntas. Dengan demikian hasil belajar siswa dapat dinyatakan tuntas karena secara klasikal mencapai $80 \%$. Keberhasilan ini memenuhi KKM 70. Dengan demikian, penerapan pendekatan pembelajaran realistik dapat meningkatkan hasil belajar siswa.

\section{KESIMPULAN DAN SARAN Kesimpulan}

Berdasarkan hasil analisis data maka beberapa kesimpulan dapat diambil bahwa keberhasilan belajar matematika pada perkalian dikelas IV SD khususnya materi tersebut mengalami peningkatan dilihat dari proses belajar dan hasil belajar pada siklus II mencapai nilai KKM dengan jumlah yang memuaskan sebanyak $90 \%$.

\section{Saran}

Bagi kepala sekolah hendaknya memberi dukungan pada guru matematika dan guru kelas untuk mengembangkan pemelajaran yang inovatif agar tercapai kualitas pemelajaran matematika yang diharapkan.

\section{DAFTAR PUSTAKA}

Abdu H. Fathani. 2008. Matematika Hakikat dan Logika. Yogyakarta: ArRuzzmedia.

Dimyati dan Mudjiono. 2013. Belajar dan Pembelajaran. Jakarta : Rineka Cipta.

Hamid, Darmadi, 2009. Kemampuan Dasar Mengajar. Bandung. Alfabeta.

Hamzah Ali. 2013. Evaluasi Pembelajaran Matematika. Jakarta : Rajawali Pers

Heruman. 2007. Model Pembelajaran Matematika di Sekolah Dasar. Bandung: Remaja Rosdakarya.

Himpunan Perundang-Undangan Republik Indonesia Tentang Sistem Pendidikan Nasional (SISDIKNAS). 2012. Bandung : Nuansa Aulia.

Kusuma, Wijaya dan Dedi Dwitagama, 2012, Mengenal Penelitian Tindakan Kelas, Jakarta: Indeks

Mulyasa, E. 2005, Kurikulum Berbasis Kompetensi, Bandung: Remaja Rosdakarya

Murni, Wahid dan Nur Ali, 2008, Penelitian Tindakan Kelas Pendidikann Agama dan Umum dari Teori Menuju Praktik Disertai Contoh Hasil Penelitian. Malang: UM press

Nana Sujana, 2005, Penilaian Hasil Proses Belajar Mengajar, Bandung: PT Rosdakarya

Purwanto, M. Ngalim, 2009, Evaluasi Hasil Belajar, Yogyakarta: Pustaka Pelajar

Suharsimi Arikunto. 2011. Prosedur Penelitian Suatu Pendekatan Praktik. Yogyakarta: Rineka Cipta.

Tim Penyusun Matematika Sekolah Dasar Kelas 5. 2011. Jakarta : Yudhistira. Wijaya Ariyadi. 2011. Pendidikan Matematika Realistik, Yogyakarta:Graha Ilmu 